\title{
2. Mostly Slow Progress on the New Model of Growth
}

\section{Ross Garnaut}

We said in the introductory chapter to the 2013 China Update book that contemporary changes in economic policy and structure were so comprehensive and profound they represented a new model of Chinese economic growth (Garnaut et al. 2013a). The new model had conventional economic and more subtle institutional dimensions. We (Garnaut et al. 2013b) and Huang et al. (2013) explored the former and Dwight Perkins explored the institutional changes (Perkins 2013).

The new model encompassed a moderately lower rate of growth of output (around 7 per cent, compared with around 10 per cent, on average, over the first 11 years of the century); a shift in resource allocation from investment to consumption and, within consumption, some increase in the relative importance of services; reversal of the tendency within the old model for growth towards greater inequality in income distribution; reduction in the adverse environmental impacts of economic growth, globally in relation to climate change and locally in relation to air and water quality; and reform of economic institutions so these outcomes would be achieved within an economy that was more market-oriented and more deeply integrated into the international economy.

I said in Chapter 2 of the 2015 book that China up to the end of 2014 was moving in the directions required by the new model of growth in terms of the main macroeconomic parameters, but that progress was slow and in its early stages. One exception to the generally slow progress was in the transformation of the environmental impact of growth, where a new trajectory of change had been established. It was too early to tell whether there had been positive progress on the qualitative, institutional dimensions of change, but there certainly had not been decisive movement to that time.

This chapter takes another look at progress to date, discussing some of the main official statements and private debates about the economy over the past year, examining some of the main changes in the economy against the objectives of official policy. 


\section{Official statements and policy on the new model of growth}

The main elements of the Thirteenth Five-Year Plan (FYP) (2016-20) were agreed to at the fifth plenary session of the Chinese Communist Party's Eighteenth Central Committee in October 2015. The plan outline was approved by the National People's Congress in March 2016 and comes into effect this year. The full planning documents await release by ministries, provincial and local governments and other public institutions. Official statements on the new plan, including in the Premier's report to the National People's Congress in March, have revealed its main elements to the public.

The new FYP is an evolutionary document. It builds on and expands earlier official statements on the new model of growth and provides us with the most elaborate statement to date on its content and implementation. An early goal is to build a moderately prosperous society by 2020, with per capita output doubling from 2010 to 2020. Implementation of what the Chinese President and Communist Party have called the 'China dream' (Xi 2012) will be achieved in an international context. This will see 'the great revival of the Chinese nation ... to stand more firmly and powerfully among all nations around the world and make a greater contribution to mankind' (Xi 2012). These themes were reiterated in the Thirteenth FYP proposal.

There will be a shift from investment to consumption, alongside a shift in the balance from exports towards domestic demand. The services share of the economy will rise from about half in 2015 to 60 per cent over the five years. Lower investment logically accompanies the lower goals for economic growth. The government remains committed to doubling total output and per capita income over the decade 2011-20. A rapid start early in the decade means that this can now be achieved with gross domestic product (GDP) growth in the range of 6.5-7 per cent over the period, with 6.5 per cent a minimum target.

The statements about the FYP expand on themes that are well known from official statements back to the beginning of the decade and from the Twelfth FYP - growth will: be of 'higher quality'; emphasise equitable distribution of income ('inclusive growth'); minimise negative environmental impacts ('green growth to build an ecological civilisation'); rely on markets at home and abroad; and deepen China's engagement with the international economy.

'Higher-quality' growth will come from an emphasis on innovation, with high reliance on science and technology and advanced use of the internet. By 2020, 60 per cent of economic output will come from applications of science and technology, which will be accompanied by decommissioning of much capacity 
in heavy industries such as steel and coal. More than RMB100 billion has been put aside to assist employees affected by structural adjustment in steel and coal to prepare for and find new jobs. There is a protectionist tinge to some of the goals for industry structure and industrial development, with some emphasis on developments of 'national champion' firms in important industries.

Inclusive growth and equity in income distribution will be pursued through improvement of infrastructure and services in rural and other poorer regions and extension of social security protections from some urban residents to the whole of the population. Seventy million people will be lifted from poverty, completing the process of removing poverty in China. The proportion of people enjoying 'middle incomes' will be increased and the incomes of people in the lower echelons of the distribution increased. Urbanisation will be one of the instruments of inclusive growth, with the proportion of urban residents rising from 55 per cent to 60 per cent of the population. The 'hukou' system of residential permits will be reformed, with all urban residents having access to urban services and barriers to movement to cities removed. The one-child limit will be raised to two children per family, which is expected to ease the growing challenges of an ageing population.

Perhaps the largest and most important policy developments relate to 'green growth' and the development of an 'ecological civilisation'. China will build a low-carbon economic system. Officials' performance indicators will be restructured to wean society from the old singular emphasis on increased output to include reference to environmental effects. There is strong emphasis on improving domestic water and air quality and conserving the natural environment throughout China. High energy efficiency, recycling of materials and increasing the proportion of energy generated from renewable sources are prominent goals. The transport sector will be restructured to rely on low-carbon technologies. There is strong commitment to meet goals on greenhouse gas (GHG) emissions articulated by President Xi Jinping in his joint statement with US President Barack Obama in Beijing in November 2014, as developed in China's statements at the United Nations (UN) meeting on climate change in Paris in December 2015. The innovation in the Xi-Obama statement was its acceptance of a limit on emissions. However, the announced limit-peaking by 2030 and earlier if possible - was not ambitious given what Chinese mitigation efforts were already achieving. There will be a national permit system to constrain emissions and a national water management system. Commercial logging of forests is to be banned.

The FYP repeats and extends the emphasis in earlier policy statements on greater use of markets for domestic and international transactions. This will require development of a rule of law and credibility in judicial processes. The proportionate role of state entities in the economy will be reduced. 
There are considerable statements about deepening international integration. Two-way movements of foreign direct investment (FDI) will be encouraged, with restrictions on entry of FDI limited by a 'negative list' and commitment to foreign enterprises being subject to national treatment. China will participate in international financial liberalisation, through making the Chinese yuan convertible on the capital account and removing barriers to its use as an international currency. Barriers to international trade will be reduced by facilitating transactions in border areas and through multilateral trade agreements and bilateral investment agreements. China's initiatives in facilitating investment in infrastructure related to trade and development through the 'One Belt and One Road' program, the Asian Infrastructure Investment Bank (AIIB), the Silk Road Fund and the new Development Bank will be important vehicles for promoting deeper integration of the Chinese economy into the global economy (Callaghan and Hubbard 2016). China will participate actively in global economic governance and in the making of rules for international exchange.

The announcements over the past year and, in particular, the FYP consolidate and extend the directions set since 2011, which involved greater departures from established directions of development when they were embodied in the Twelfth FYP (2011-15). The China Update group had to invent a name for the change of direction when it was first apparent - calling it the new model of Chinese growth. It now has an official name: the 'new normal'. How is performance within the new normal shaping up?

\section{Economic growth outcomes and prospects}

Chinese GDP increased by 6.9 per cent in 2015- the lowest rate of growth since 1990, but within the 'new normal' range (Figure 2.1). Among many signs of weakness, wages rose more slowly than in recent years. The weak impulse of growth became more evident early in 2016. GDP growth in the year to the March quarter fell to 6.7 per cent, with many market participants and analysts expressing anxiety about growth continuing to fall until it was well below the official target range. Premier Li Keqiang seemed to be setting out to remove these concerns in his March statements after the National People's Congress, which underlined the importance of meeting the target rate of growth.

In an economy in which market dynamics are important to total investment and consumption, how can the government be confident of delivering on its aim to maintain growth at 6.5 per cent per annum or higher? The short answer is that it cannot be certain that it can do so while maintaining progress on structural reform within the new model of growth. 


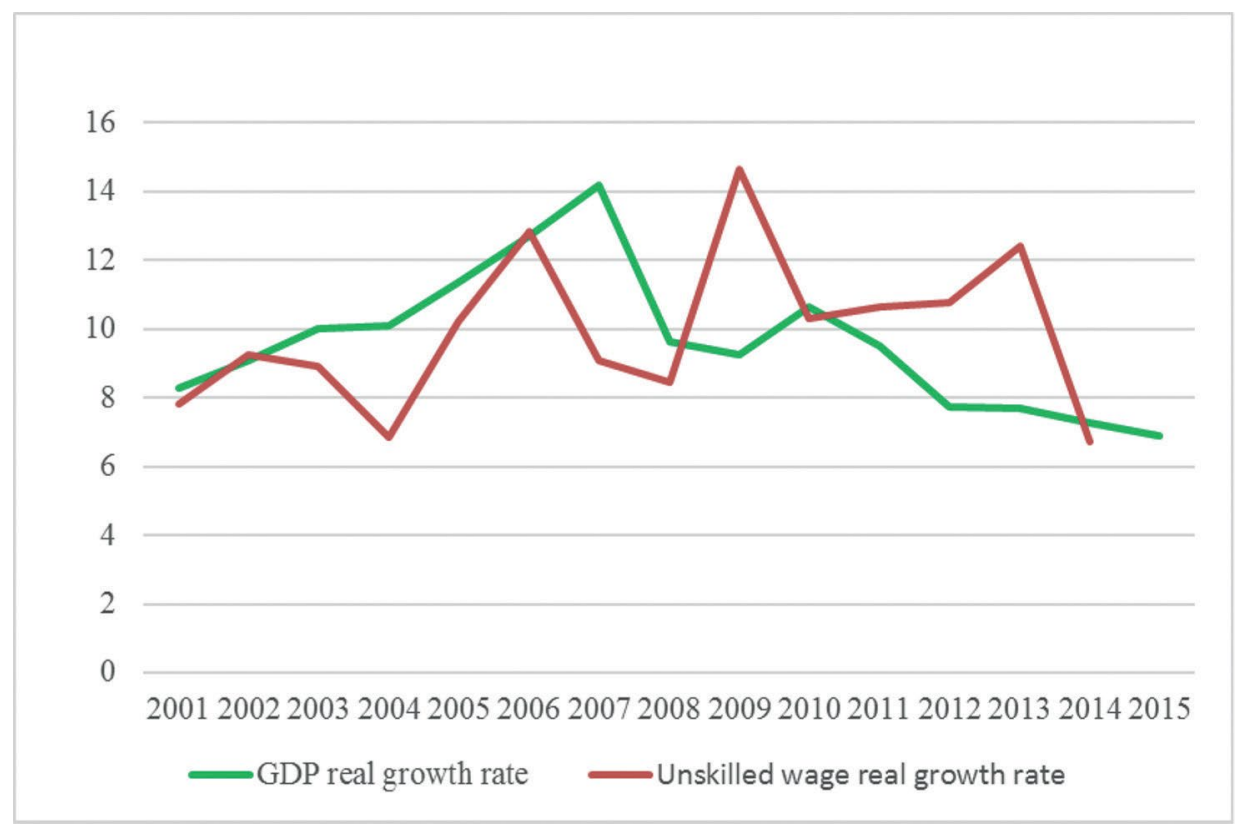

Figure 2.1 GDP real growth rate and unskilled wage real growth rate Sources: World Bank (various years); NBS (various years).

In the short term, there is a risk that the anticipated decline in business investment as a share of economic output will proceed more rapidly than the anticipated increase in consumption. The government will then face a choice between reverting to fiscal and monetary expansion to maintain growth in demand or maintaining the pace of structural reform. Fiscal and monetary expansion in the forms favoured in earlier years tends to increase the role of public enterprises and the public sector more generally, increases the indebtedness of public institutions, reduces reliance on market exchange and slows reform of institutions that are important in the new model of growth. Certainly, the immense Keynesian fiscal and monetary expansions that insulated China from the worst effects of the East Asian Financial Crisis of 1997-99 and the Global Financial Crisis (GFC) of 2008 extended the life of an old, obsolete and, in important ways, damaging model of growth.

The new model of economic growth embodies structural change at an immense scale. One can define a possible path of smooth adjustment that would see rapid but gradual offsetting changes in the main growth parameters that together ensure the continuation of reasonably strong growth in output, employment and incomes of most people. But it is possible - maybe likely - that intended investment falls for longer than intended consumption rises. On the supply side, productivity may not rise to compensate sufficiently for lower contributions from other sources of growth in output and incomes. In either case, but probably 
more quickly and immediately damaging where the shortfall is on the demand side, there would be disruption of growth in output and incomes. Disruption would introduce risks of financial or political dislocation compounding the initial loss of growth momentum.

The possibility of rough adjustment has loomed large over the past year. There has been anxiety that the fall in business investment-in particular, in relation to urban real estate - had been proceeding more rapidly than the increase in consumption, with contractionary consequences. There were signs in late 2015 and early 2016 that declining activity in urban real estate and associated heavy industry was leading to lower growth than anticipated in official statements. Concern about excessive reduction in the trajectory of growth led to substantial compensatory fiscal and monetary expansion and to some public debate about whether there had been reversion to an emphasis on growth at the expense of institutional reform. The Communist Partyundoubtedly from the highest authority - sought to bring the debate to an end with a prominent article in the People's Daily in May on the importance of holding firm to structural change associated with reform.

Smooth adjustment was challenged through 2015 by declining values and associated panic in the Shanghai and Shenzhen stock markets. Official intervention to halt the fall through suspension of trading and official purchase of stocks initially increased uncertainty and exacerbated the panic. The interventions were a setback for reform to build a more market-oriented economy. The main long-term legacy is probably an acceptance for the future that arbitrary interventions in markets are likely to do more harm than good.

Adjustment to the new model of growth requires for a while an absolute reduction in total investment and not just a fall in the investment share of expenditure. Change in the required level of investment - and therefore demand for inputs into investment - depends not on the rate of growth in the economy, but on changes in the rate of growth. The rate of growth of output is expected to fall by about one-third within the new model of growth-from about 10 per cent per annum to 6.5-7 per cent (and eventually to lower levels). In the absence of changes in the productivity-related influences that determine the capital-output ratio, the level of investment can be expected to fall by a similar proportion. Consumption has to rise quickly and by a large amount to maintain domestic demand that is consistent with maintenance of the new, lower potential rate of growth.

The new model of growth is meant to rely much more heavily on expansion of domestic demand and less on international demand as revealed in growth in net exports. There was large and rapid progress in reducing net exports (the trade surplus) and also the current account surplus as domestic investment 
increased in the fiscal and monetary expansion in response to the GFC. Over the past two years, there has been some reversal of this tendency. Weak domestic demand has been partially compensated by an increase in the trade surplus.

The tendency since 2013 for the trade surplus to rise again from the much lower levels after the GFC strengthened in 2015 (Figure 2.2). The trade surplus has increased to levels that put in doubt progress towards one of the central macroeconomic objectives of the new model of growth: increased reliance on domestic rather than international demand. There was a major correction to the hugely excessive surpluses immediately before the GFC, but the lift in the surplus over the past two years has removed half of the early progress. The current account surplus has not increased in line with the trade surplus, partly because of diminished earnings on overseas investments in the contemporary environment of low global interest rates.

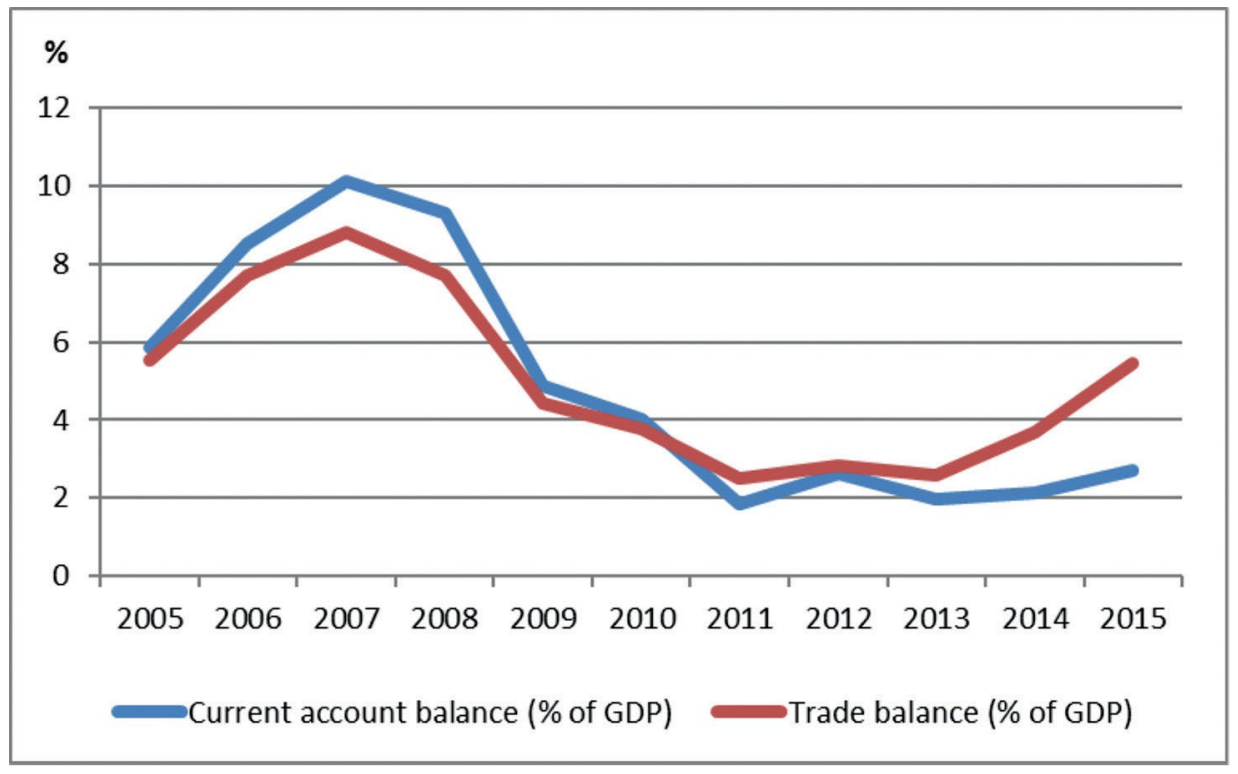

Figure 2.2 Trade and current account balances

Sources: World Bank (various years); State Administration of Foreign Exchange (2015); and NBS (various years).

Some aspects of China's international economic strategy are designed to underpin a continuing trade surplus and to reduce the pressures for domestic structural change. This will help to keep the scale of structural adjustment within manageable limits. The developed countries and China in recent times share a tendency for total savings to exceed investment. Capital outflows from these countries have tended to be disproportionately among themselves rather than to lower-income developing countries. Larger movements of capital to lower-income economies would support growth and employment in the 
developed countries themselves, as well as supporting higher levels of growth in developing countries. Capital flows from developed to developing countries would be most valuable to the home and host countries if they were concentrated in long-term investments in income-generating infrastructure. Higher levels of infrastructure investment in developing countries, in turn, would help to hold up demand for capital goods and inputs into construction and so reduce the amount of structural change that is necessary in the developed countries and China as a result of lower growth rates and investment levels.

The big barrier to higher levels of investment from the developed countries and China in the developing countries has been the absence of institutions to support confidence in market exchange and reduce perceptions of risk around such transactions. Private markets alone have not been able to provide the necessary confidence in high levels of investment in infrastructure from developed to developing countries. China's strong focus on the building of institutions for channelling investment from itself and other high-income countries to developing countries - the AIIB, the new Development Bank, the Silk Road Fund and the financial institutions being established around the 'Belt and Road' initiative - can be seen as filling this gap. Already China's efforts have spurred increased activity in developed countries in channelling funds to support infrastructure investment in developing countries-for example, through increased Japanese support for the lending of the Asian Development Bank.

It is possible that the scale of international investment supported by the new public lending institutions could end up being large enough to make a larger trade surplus - with higher proportions of capital goods and materials - a permanent feature of Chinese macroeconomic balance. This would ease the extent of domestic contraction of industries supplying capital goods within China within the new model of growth. If China's example were influential internationally, it could be helpful to the maintenance of employment and growth in the developed countries at a time of macroeconomic stress. It would be strongly supportive of development in low-income countries.

Figure 2.3 shows only modest progress in reducing the investment share and raising the consumption share of expenditure. It is change in the right direction, but slowly. A question arises: if the investment share of expenditure remains near where it was before the high point of the old model of growth, why has growth in output fallen by one-third? The answer is that total factor productivity (TFP) growth is much lower than it was. Much contemporary investment is wastefully deployed. This spoils the objective of the new normal to apply a larger part of the benefits of growth to increases in consumption and, more broadly, to raising the living standards of the Chinese people. 


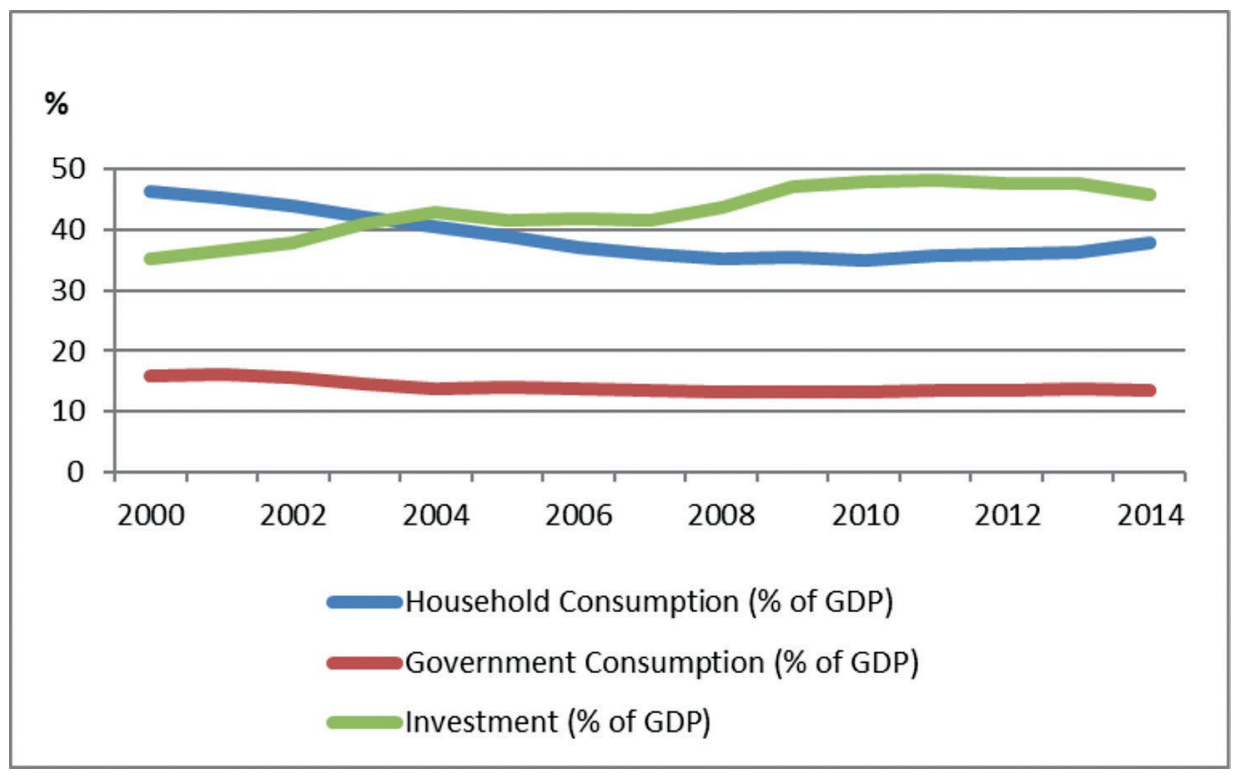

Figure 2.3 Consumption and investment share of GDP Source: NBS (various years).

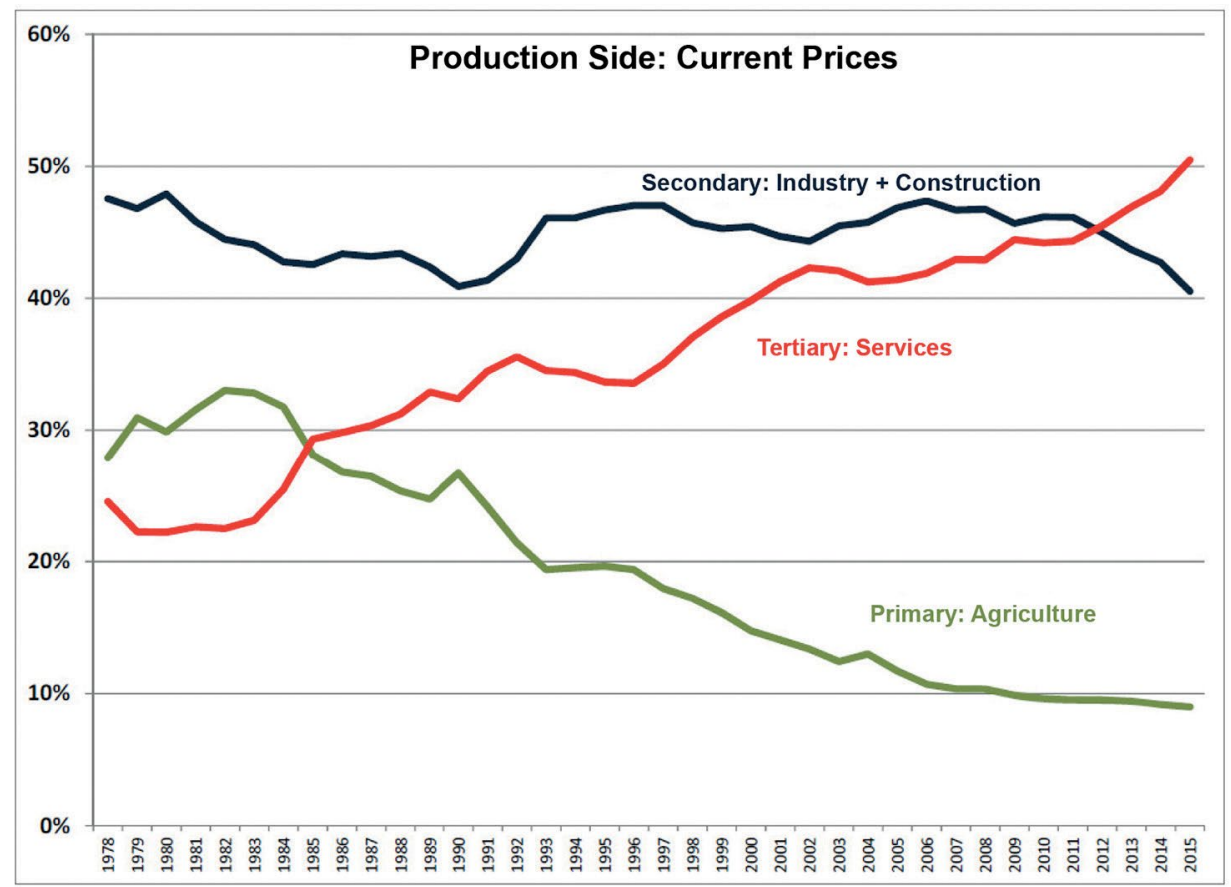

Figure 2.4 Composition of GDP (per cent)

Source: Naughton (2016). 
Figure 2.4 shows a rapid increase in the services share of output when all goods and services are valued at current prices. The tendency emerged early in the reform period and has accelerated within the new model of growth since 2011. Naughton (2016) has noted that the increase in the services share is smaller when production is measured in constant prices. That is commonly the case in economies experiencing rapid growth in real wages and does not remove the significance of the major structural change that is taking place.

\section{Institutional change and productivity growth}

In the medium and longer terms, there is great uncertainty about the rate of TFP growth that will be achieved under the new model.

Smooth adjustment to a lower but reasonably strong growth rate, as envisaged in the new normal, would require the maintenance or even some acceleration of TFP growth back to levels preceding the GFC to offset part of the declines in the contributions of growth to the capital stock and labour. Rising real wages introduce pressure to raise productivity. The focus on improvement of the institutions for market regulation and exchange can raise productivity. The focus on increased investment in education within the new model of growth combines with the large decline in the school-age population to greatly improved labour quality, which shows up as increased TFP. Success in raising productivity growth depends especially on the institutional reforms discussed by Perkins (2013) in his contribution to this series. It depends on maintenance of openness to the international economy in all of its dimensions. It requires far-reaching financial system reform to allow capital to move quickly and in large quantities to its most productive uses. Strong growth in TFP requires acceptance of rapid changes in the composition of economic activity in line with rapidly changing comparative advantage. It requires improvement of market institutions, including through increased transparency and reliability of state mechanisms for regulating legal relations between the state and private entities and among private businesses. These improvements require strengthening of rights to intellectual and other property. Success in maintaining and lifting productivity growth requires easy and low-cost transfers of economic information within China and between Chinese and overseas individuals and enterprises.

Most of these requirements are accepted within the new normal model of Chinese growth - accepted, but difficult to apply.

There has been some progress in some areas of institutional and market reform but not much and not in many areas. And, in some areas requiring relatively free access to information through the internet, there has been retrogression. There has not yet been any sign of a lift in the low rates of productivity growth 
that emerged in the aftermath of the fiscal and monetary expansions of 2008 and 2009, which were discussed in Chapter 2 of the 2015 China Update volume. Indeed, data for 2014 have repeated the bleak story from 2013: there was no increase at all in TFP growth, with growth in output coming almost entirely from increases in the capital stock. Measurement is difficult, but good enough for us to be confident that TFP growth remains well below rates that were typical of the first three decades of reform (Figure 2.5).

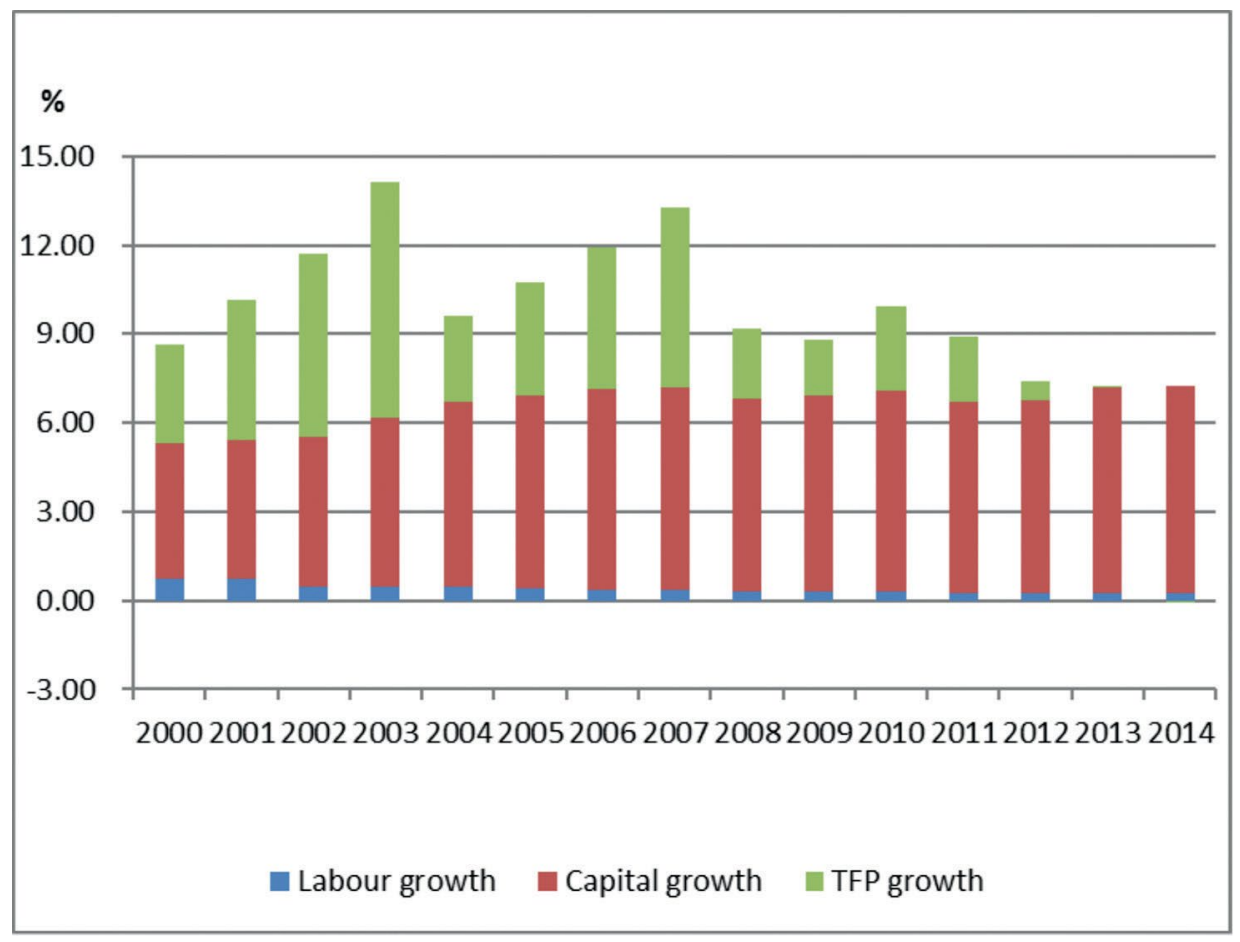

Figure 2.5 Contributions of components of GDP growth

Source: The Conference Board Total Economy Database (2015).

The continued-indeed, increased-reliance on growth in the capital stock with the implementation of the new normal would have massive effects on the industrial structure of demand. In particular, investment uses metals and energy far more intensively than consumption, so that sharply lower investment means a slump in demand for the products of heavy industry that had central roles in the old model of growth. Coal, steel and cement are the most prominent of the industries subject to lower demand growth - with coal also affected by the shift to low-emissions sources of power generation that follows the elevation of environmental amenity among national objectives. The need for contraction in production capacity of steel and coal figures prominently in the 2016 planning 
documents and official statements. The slow progress so far in reducing the investment share of GDP suggests that the greater part of adjustment to the new normal remains in the future.

The slowing of the rate of urbanisation after the turning period of Chinese economic development induces deceleration in growth in demand for all of the infrastructure required by a growing urban population, including housing and transport infrastructure. As with demand for investment goods, this induces an absolute fall in demand for many goods that occupied a large place within the old model of growth. This is an important part of the current anxiety about oversupply of housing in many Chinese cities - an oversupply that is transmitted with acceleration into industries like steel and cement, which supply inputs into real estate and infrastructure development.

The massive structural adjustment required by the new model of growth compounds risks of disruption that emerged in the mature stage of the old model of growth. The unprecedentedly high investment shares of GDP channelled disproportionately through state agencies led to overinvestment in some areas of heavy industry and infrastructure. Provincial and local government sponsorship of real estate developments in particular had been associated with strong growth in revenue during the later years of the old model of growth. Financial institutions that had provided funds for infrastructure and heavy industry are vulnerable to the deterioration in the fortunes of these mainstays of the old growth model - as are provincial and local governments, whose revenues came to depend excessively on new urban development during the period of rapid, investment-led growth. The pullback in investment in urban development and heavy industry under the new model has led to severe imbalances in local government finances and vulnerability on the balance sheets of many financial institutions (Yu 2009; Wong 2015). Financial reform is necessary for success in transition to the new model of economic growth, but is inhibited by the fragility of financial institutions deriving from the lending patterns of the era of investment-led growth.

Little or no progress seems to have been made in dealing with the accumulation of public debt, most importantly, at subnational government level.

The labour supply contribution to growth was small but positive early in the century and has since shrunk to negligible levels. That it remains slightly positive in the face of a decline in the population age cohorts that are conventionally considered to be the years of employment reflects some increase in labour force participation rates. 
The growth in the capital stock has been the major contributor to growth in output through this century so far, with 2003 the only exception. Its absolute contribution to growth reached a high plateau in about 2006 and has remained there since, despite the contrary expectations from the new model of growth.

The low levels of TFP growth since the fiscal and monetary expansions in response to the GFC in 2008 were noted for the period to 2013 in last year's book. The data show that they continued through 2014 (Figure 2.5). There is no sign of a change in 2015. Economic development since 2011 has been characterised by greater reliance on increases in the capital stock than at any time in the reform period from 1978.

In a scenario of smooth adjustment to China's new model of growth, steady or rising contributions from increased productivity could have offset a decline in the capital contribution. Here the evidence points to the reverse: since the GFC of 2008, productivity growth has declined markedly and economic growth is now more reliant than ever on growth in the capital stock. The successful transition to lower but strong growth within the new model of growth requires this to be corrected. There is as yet no sign of correction.

\section{Progress on inclusive growth}

There has been modest movement in the desired directions for most of the measures contemplated in the new model of growth for their contribution to equity in income distribution.

The powerful labour market pressures for reduced inequality through the growth in wages relative to other incomes have diminished since 2013 as weaker labour demand growth has moderated the growth in real wages (Figure 2.1). Nevertheless, labour market developments have been contributing substantially to reduction of overall inequality as measured by the Gini coefficient (Figure 2.6). China's new model of growth - or, more generally, contemporary economic circumstances - has secured a reversal of the powerful tendencies for income disparities to widen in the quarter-century from the mid-1980s.

The extension of social security arrangements to a higher proportion of urban residents and gradually to rural residents has begun, but, to date, it is a modest beginning.

Local resistance to breaking down restrictions on migrants' rights has been strong and has slowed implementation of hukou reforms. 


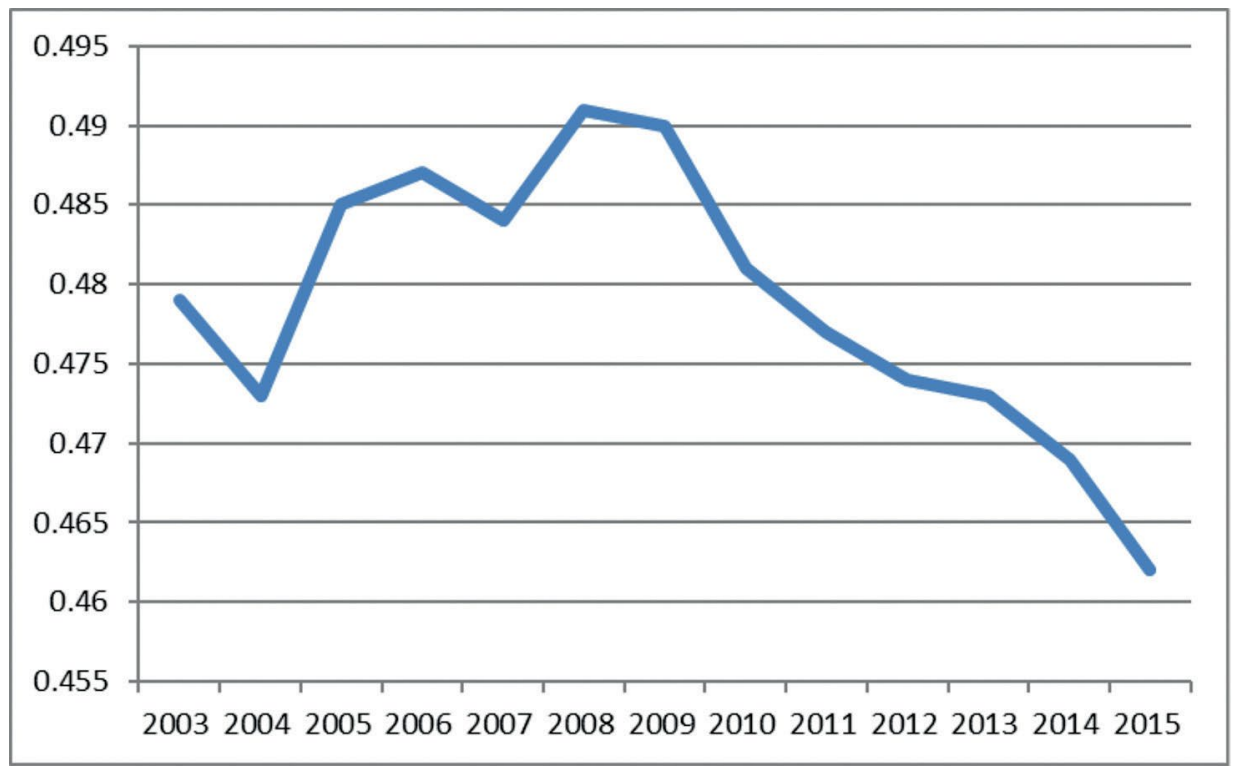

Figure 2.6 Gini coefficient in China

Source: NBS (various years).

\section{Environmental effects of growth}

The old model of growth had a devastating impact on the natural environment of China and the world. The growth in Chinese GHG emissions through the first 11 years of this century accounted for most of the substantial global increase. Chinese emissions greatly increased the urgency of global action on climate change. And yet there was no inclination to change China's contribution to the global problem before 2009.

The Chinese contribution to global emissions came primarily from coal; China contributed virtually the whole of the large increase in global coal consumption in the first 11 years of this century (Figure 2.8). At the same time as growing Chinese coal use heightened the urgency of global action on climate change, it imposed immense pressures on local air quality. This generated large public health problems and pressures for reform (Garnaut 2015).

China continues to make great progress on reducing the global and domestic environmental impacts of economic growth. This is the clearest example so far of success in the new model of growth.

Changes in the growth model have reduced the rate of growth in demand for energy. Policies motivated by domestic and global environmental concerns have radically reduced the importance of coal as a source of energy. These effects 
from the energy sector have been reinforced by reduced emphasis on investment in heavy industry and infrastructure with its intense use of metals (especially steel) and cement, the manufacture of which utilises coal intensively.

Table 2.1 records the continuing progress in reducing the electricity intensity of economic activity and the importance of fossil fuels in the generation of electricity. China aims to greatly increase the efficiency with which it uses energy in economic activity. Success in this aim is evident in Table 2.1, where the rate of growth in electricity demand has been well below the rate of GDP growth since 2012. Note that the decline in coal use in 2014 and 2015 is greater than the reduction in thermal power generation, for two reasons. First, while thermal power generation is mostly coal, there has been an increase in thermal generation from zero emissions (biomass) and lower emissions (gas) sources. Second, the continued replacement of less environmentally efficient by larger and more environmentally efficient coal generation plants has led to steady reduction in the amount of coal used per unit of power generated (and also some reduction in carbon emissions per unit of coal used).

Table 2.1 Electricity generation by source, 2010-15

\begin{tabular}{|l|r|r|r|r|r|r|r|r|r|r|r|r|}
\hline & \multicolumn{5}{|c|}{ Quantity (million Mwh) } & \multicolumn{5}{|c|}{ Rise over previous year \% } \\
\hline Year & Total & Thermal & Hydro & Nuclear & Wind & Solar & Total & Thermal & Hydro & Nuclear & Wind & Solar \\
\hline 2010 & 4228 & 3416 & 687 & 75 & 49 & 0 & 14.9 & 13.4 & 20.1 & 6.7 & 78.9 & 73.7 \\
\hline 2011 & 4731 & 3900 & 668 & 87 & 74 & 1 & 11.9 & 14.2 & -2.7 & 16.7 & 49.9 & 459 \\
\hline 2012 & 4986 & 3925 & 856 & 98 & 103 & 4 & 5.4 & 0.6 & 28.1 & 12.7 & 39.1 & 412 \\
\hline 2013 & 5372 & 4222 & 892 & 112 & 138 & 9 & 7.7 & 7.6 & 4.2 & 14.3 & 34 & 125 \\
\hline 2014 & 5573 & 4205 & 1070 & 126 & 156 & 23 & 3.3 & -0.4 & 20 & 12.5 & 13 & 155.6 \\
\hline 2015 & 5605 & 4097 & 1114 & 166 & 157 & 38 & 0.6 & -2.6 & 4.1 & 31.7 & 18.6 & 65.2 \\
\hline
\end{tabular}

Source: China Electricity Council (various years).

More than the whole of the increase in electricity generation has come from non-thermal sources, with zero emissions, since 2013. Hydro-electricity remained the most important source of zero-emissions power. Weather limited the growth in hydro-electric generation in 2015, although investment in capacity continued at a rapid rate. Hydro-electric output can be expected to return to reasonably strong growth in future years. Wind was the secondlargest source of zero-emissions energy again in 2015, with the rate of growth in supply rising despite the increased scale of generation. Nuclear power output returned to strong growth, in response to the resumption of investment in new capacity after the initial review of safety and policy spurred by the Fukushima disaster in Japan. Solar power again grew more rapidly than any other source of electricity, although the rate of growth continues to moderate as the level of output increases. 
To the extent that the 'thermal power' category in Table 2.1 is read as a proxy for coal generation, the table underestimates the decline of emissions from electricity generation. While coal contributes most to thermal generation, there is an increasing contribution from biomass with zero emissions and from gas with much lower emissions than coal. This has displaced a small part of coal generation. Coal use in electricity generation has fallen more rapidly than thermal power output.

Chinese emissions from industry are also large by global standards. The high levels of investment in the old model of growth made China the locus of about half of steel and cement production, the manufacture of both of which uses coal intensively.

Figure 2.7 shows how China contributed almost all of the growth in global steel use from the turn of the century until the new model of growth changed the pattern of demand in 2012. Steel consumption reached its peak in 2013, and has since fallen significantly. Figure 2.7 shows how this caused global consumption of steel to stagnate in 2014 and 2015 despite modest growth in demand elsewhere.

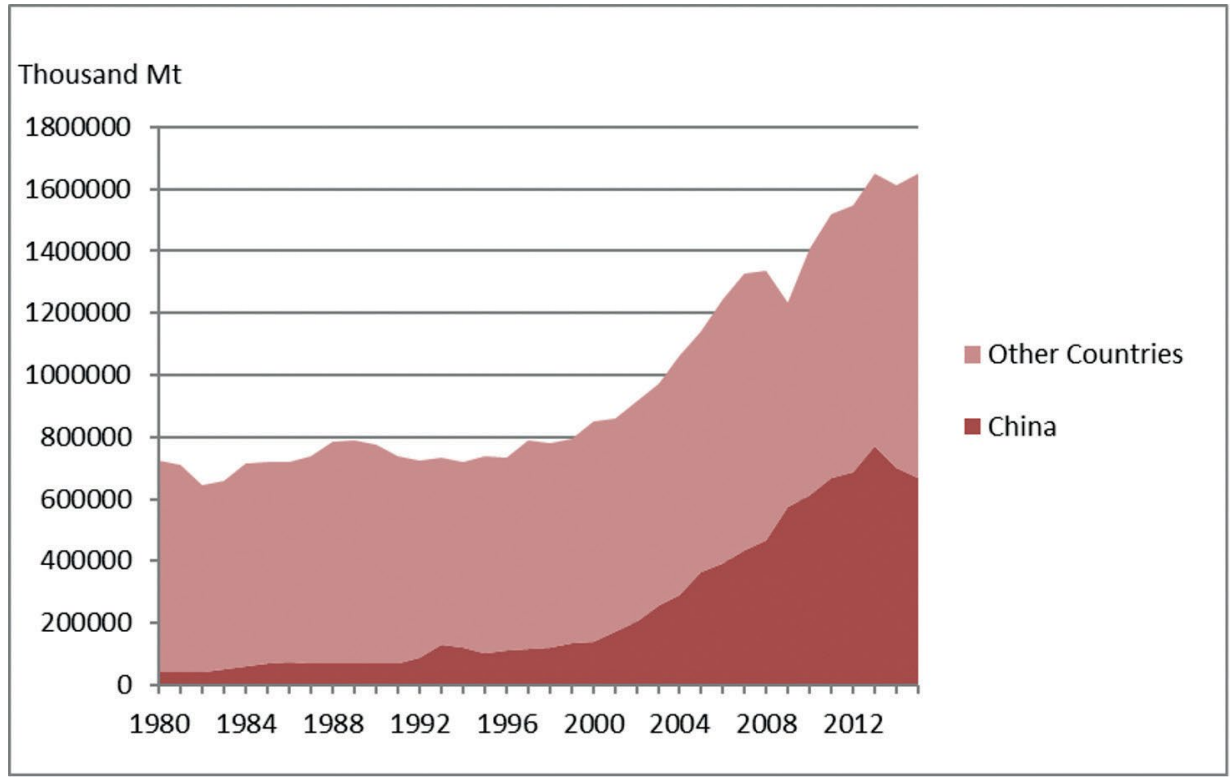

Figure 2.7 Steel consumption in China compared with other countries

Sources: World Steel Association (2015); and author's estimation.

Chinese steel production fell over these years, but much less rapidly than consumption. The difference was poured on to world markets, depressing steel prices below the cost of production in China and elsewhere. This generated a visceral protectionist reaction in much of the world. The increase in protection 
against Chinese steel imports into developed countries in 2015 and early 2016 is the most important retreat into protectionist policy in the global economy in the twenty-first century.

The environmental pressures from the use of coal in steelmaking and the losses being incurred by most steel enterprises have caused the Chinese Government to seek large reductions in steel output and manufacturing capacity. The reduction in capacity is being sought from use of blast furnaces. The environmental objectives of the FYP favour recycling of steel, and electric arc production from scrap is likely to steadily increase in importance through and beyond the period of transition to the new model of growth. The FYP and other policy statements have spoken of a reduction of 100-150 million tonnes of steelmaking capacity, which would make a substantial contribution to achieving the balance between global supply and demand. It is possible - I would say likely - that Chinese steel production from blast furnaces reached its all-time peak in 2013.

The declines in coal-based power generation and in steel and cement production are the main sources of a dramatic change in trajectory in Chinese coal use. After contributing nearly all of the growth in global coal consumption from the turn of the century to 2012, China has contributed its full share of a decline in coal use since then (Figure 2.8). GHG emissions probably fell in China and the world in 2015, for the first time outside recessionary circumstances in the major emitting countries. The reduction in Chinese coal use was the most important contributor to the decline in global emissions.

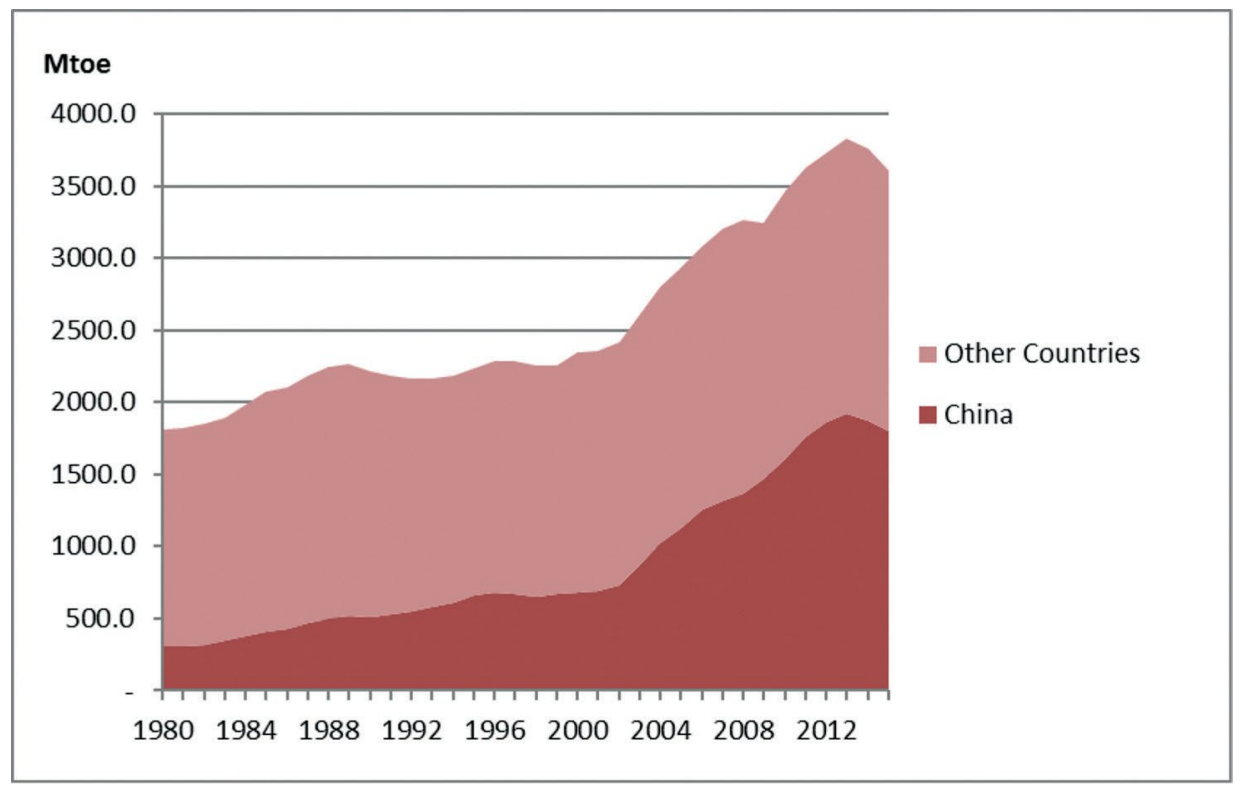

Figure 2.8 Coal consumption in China compared with other countries

Sources: BP (2015); and author's estimation. 
The changes are of great importance to the quality of the Chinese domestic environment and to the prospects for the world avoiding extremes of humaninduced climate change. China has arrested growth in coal use and emissions well in advance of its commitments to the international community in Beijing and Paris. However, while the turnaround in China's use of coal and its output of GHGs is of immense value to China and the global community, the levels of emissions remain well above reasonable assessments of the natural environment's capacity to absorb them without large problems.

The FYP envisages systematic efforts to apply science and technology to reducing carbon emissions throughout the economy. In the transport sector, the focus is on shifting from liquid and gaseous fossil fuels to zero-emissions electricity as a source of energy. Current plans envisage China having five million electric cars on the road by 2020 and increasing rapidly in number after that. This would provide the scale for mass production within China and reduction in costs for consumers everywhere, just as rising Chinese use and production of photovoltaic panels has reduced the costs of solar energy in all countries.

The recent progress in reducing Chinese coal use and GHG emissions is of extraordinary dimension, but it has to be only the beginning of a continuing effort. The implementation of the Paris agreement on climate change mitigation will require an intensification of the recent reduction in carbon emissions, until net emissions have been reduced to zero in the third quarter of the century.

China has made a start on the transition to its new model of growth. In terms of environmental impact, it has made a much larger start than close observers a few years ago would have thought possible. But all elements of transition have a long way to go.

As Premier Li Keqiang said in March 2016, the transition is a difficult one and it would be surprising if there were no disruptive bumps in the road.

\section{References}

BP (2015), Energy charting tool, London: BP. Available from: bp.com/en/global/ corporate/about-bp/energy-economics/energy-charting-tool.html.

Callaghan, M. and Hubbard, P. (2016), The Asian Infrastructure Investment Bank: Multilateralism on the Silk Road, China Economic Journal 9(2): 116139.

China Electricity Council (various years). Available from: www.cec.org.cn/ guihuayutongji/tongjxinxi/. 
The Conference Board Total Economy Database (2015). Available from: www.conference-board.org/data/economydatabase/index.cfm?id=27762.

Garnaut, R. (2015), The new model of growth and the global resources economy, in L. Song, R. Garnaut, F. Cai and L. Johnston (eds), China's domestic transformation in a global context, Canberra and Beijing: ANU Press and Social Sciences Academic Press.

Garnaut, R., Cai, F. and Song, L. (eds) (2013a), China: A new model for growth and development, Canberra and Beijing: ANU E Press and China Social Sciences Academic Press.

Garnaut, R., Cai, F. and Song, L. (2013b), China's new strategy for long-term growth and development: Imperatives and implications, in R. Garnaut, F. Cai and L. Song (eds), China: A new model for growth and development, Canberra and Beijing: ANU E Press and China Social Sciences Academic Press.

Huang, Y., Fang, F., Xu, P. and Xin, G. (2013), The new normal of Chinese development, in R. Garnaut, F. Cai and L. Song (eds), China: A new model for growth and development, Canberra and Beijing: ANU E Press and China Social Sciences Academic Press.

National Bureau of Statistics of China (NBS) (various years), China statistical yearbook, Beijing: China Statistics Press. Available from: www.stats.gov.cn/ english/Statisticaldata/AnnualData.

Naughton, B. (2016), Rebalancing, restructuring and reform: China 2016, Sydney: Reserve Bank of Australia. Available from: rba.gov.au/publications/ confs/2016/pdf/rba-conference-2016-naughton.pdf.

Perkins, D. H. (2013), New institutions for a new development model, in R. Garnaut, F. Cai and L. Song (eds), China: A new model for growth and development, Canberra and Beijing: ANU E Press and China Social Sciences Academic Press.

State Administration of Foreign Exchange (2015), Annual Report of State Administration of Foreign Exchange. Available from: www.safe.gov.cn/wps/ portal/english/Home.

Wong, C. (2015), Can Xi Jinping's reforms be implemented? Let's look at China's fiscal architecture, Presentation to Centre for Contemporary Chinese Studies Academic Seminar, University of Melbourne, Melbourne, 5 March.

World Bank, World Development Indicators. Available from: data.worldbank. org/country/china. 
World Bank (various years), World Development Indicators. Available from: data.worldbank.org/data-catalog/world-development-indicators.

World Steel Association (2015), Crude steel production 2014-2015, Brussels: World Steel Association. Available from: worldsteel.org/statistics/crudesteel-production.html.

Xi, J. (2012), Speech to the Politburo Standing Committee Members' meeting, 12 November 2012. Available from: www.bbc.com/news/world-asiachina-20338586.

Yu, Y. (2009), China's policy responses to the global financial crisis, The 2009 Snape Lecture, Melbourne: Australian Productivity Commission. Available from: pc.gov.au/news-media/snape-lectures/yongding. 
This text is taken from China's New Sources of Economic Growth: Reform, resources and climate change, Volume 1, edited by Ligang Song, Ross Garnaut, Cai Fang \& Lauren Johnston, published 2016 by ANU Press, The Australian National University, Canberra, Australia. 